\title{
MENINGKATKAN KEMAMPUAN MEMBACA PERMULAAN MELALUI MEDIA FLANNEL PINTAR KELOMPOK A TK NEGERI PEMBINA BANTUL
}

\author{
Partijem \\ Tamak Kanak-Kanak Negeri Pembina Bantul \\ bpartiela@gmail.com
}

\begin{abstract}
Abstrak
Penelitian ini bertujuan meningkatkan kemampuan membaca permulaan melalui flannel pintar pada kelompok A2 TK Negeri Pembina Bantul. Jenis penelitian ini adalah Penelitian Tindakan Kelas kolaboratif yang menggunakan model Kemmis \& Mc Taggart. Subjek penelitian ini adalah anak kelompok A2 sebanyak 22 anak yang terdiri dari 10 anak perempuan dan 12 anak laki-laki. Objek penelitian ini adalah kemampuan membaca permulaan. Metode pengumpulan data dilakukan melalui observasi dan dokumentasi. Teknik analisis data dilakukan secara deskriptif kuantitatif dan kualitatif. Hasil penelitian menunjukkan bahwa kemampuan membaca permulaan dapat meningkat setelah diberikan tindakan menggunakan flannel pintar yang dilakukan secara bersamaan dengan teman menyerupai perlombaan, serta pemberian reward secara kongkret yakni memberi bintang dari kertas berwarna yang di tempel di papan karya. Peningkatan kemampuan membaca permulaan tersebut di atas dapat terlihat secara optimal dari hasil data observasi dan dokumentasi yang diperoleh pada setiap siklusnya. Peningkatan dari pra tindakan ke Siklus I sebesar 16,6\% dan,dari Siklus I ke Siklus II mengalami peningkatan sebesar 41,6\%. Anak yang berada pada kriteria Berkembang Sangat Baik sebelum tindakan berjumlah 2 anak (16,6\%), pada Siklus I berjumlah 6 anak 34,4 \% dan pada Siklus II berjumlah 11 anak $(91,6 \%)$.
\end{abstract}

Kata kunci: kemampuan membaca permulaan, media flannel pintar, kelompok A2

\section{IMPROVING THE EARLY READING SKILL THROUGH SMART FLANNEL MEDIA IN GROUP A TK NEGERI PEMBINA BANTUL}

\begin{abstract}
This study aims to improve the early reading skills through smart flannel in A2 TK Negeri Pembina Bantul group. This type of research is collaborative class action research using Kemmis \& Mc Taggart model. The subjects of this research were children of A2 group as many as 22 children consisting of 10 girls and 12 boys. The object this study was the early reading skills. Methods of data collection were done through observation and documentation. Data analysis technique was done descriptively quantitative and qualitative. The results show that the early reading skills increased after the action was conducted using smart flannel that was done simultaneously with friends resembling the race, as well as giving concrete rewards that gave the star of colored paper on the board. The improvement of the early reading skills was seen optimally from the observation and documentation data obtained in each cycle. The increase from pre-action to cycle I was $16.6 \%$ and from cycle I to cycle II was $41.6 \%$. Children included in the criteria Developed Very Good before the action amounted 2 children (16.6\%), in the first cycle amounted to 6 children $34.4 \%$ and in cycle II amounted to 11 children $(91.6 \%)$.
\end{abstract}

Keywords: Early reading skills, smart flannel media, group A2 


\section{PENDAHULUAN}

Taman Kanak-kanak merupakan pendidikan anak usia dini yang diselenggarakan secara formal sebagaimana dinyatakan dalam UndangUndang Sistem Pendidikan Nasional Nomor 20 Tahun 2003 Pasal 28 "Pendidikan Anak Usia Dini pada jalur formal berbentuk Taman Kanak-kanak (TK), Raudhatul Athfal (RA), atau bentuk lain yang sederajat”. Usia TK berkisar 4-6 tahun. Kisaran yang diselenggarakan di Indonesia dikelompokkan ke dalam kelompok A usia 4-5 tahun dan kelompok B usia 5-6 tahun (Permendikbud No 146 Tahun 2014). Pada usia 4-6 tahun atau berada dalam kelompok A dan B, anak masih mengalami masa keemasan (the golden ages) yang merupakan masa dimana anak mulai peka atau sensitif untuk menerima berbagai stimulasi dan pendidikan.

Salah satu perkembangan yang perlu distimulasi adalah perkembangan bahasa. Perkembangan bahasa meliputi perkembangan bahasa reseptif dan perkembangan bahasa ekspresif. Salah satu komponen yang di perlu mendapat perhatian yakni membaca permulaan. Berdasarkan wawancara dan keinginan orang tua bahwa anak lulus TK bisa membaca, untuk melanjutkan pendidikan selanjutnya.

Usaha yang dilakukan guru dalam meningkatkan membaca permulaan pada anak yaitu dengan melakukan pembelajaran sambil bermain menggunakan media pembelajaran yang menarik. Berdasarkan hasil observasi yang dilakukan di TK Negeri Pembina Bantul pada anak 4-5 tahun atau TK kelompok A dapat didiskripsikan sebagai berikut:

Kegiatan observasi dilaksanakan sebelum penelitian atau tindakan, didapatkan hasil bahwa kemampuan membaca sebagian besar anak yaitu 16 dari 22 anak masih berada pada kriteria Mulai Berkembang (MB). Beberapa anak masih pasif dan mengalami kesulitan dalam: 1. Mengenal simbol-simbol, 2.
Mengenal suara hewan/benda yang ada di sekitarnya, 3. Membuat coretan yang bermakna, 4. Meniru (menuliskan dan mengucapkan ) hururf A-Z (Permendikbud No 137 Tahun 2014).

Pembelajaran sambil bermain mmebutuhkan media yang sesuai dengan materi yang disampaiakn, kegiatan yang dilaksanakan dan sesuai tingkat berpikir anak. Pembelajaran membaca permulaan membutuhkan media. Media pembelajaran untuk anak TK seyogyanya dapat menimbulkan motivasi dan ketertarikan anak sehingga anak belajar seperti bermain serta tujuan pembelajaran dapat tercapai secara optimal (Nana Sudjana dan Ahmad Rivai, 2002: 2). Guru seyogyanya berusaha mencari berbagai media yang tepat atau sesuai dengan perkembangan anak. Media yang mendukung pembelajaran membaca permulaan kemampuan membaca anak dapat meningkat. Sedangkan strategi untuk anak TK yang tepat seharusnya berpusat pada anak, bukan pada guru karena dengan berpusat pada anak akan lebih menimbulkan kebermaknaan dalam memperoleh pengalaman sehingga ilmu yang didapat mampu terserap dengan baik.

Ketika dilakukkannya observasi pada awal pembelajaran berlangsung, terdapat satu masalah yang dihadapi yakni rendahnya kemampuan anak dalam membaca permulaan. Seperti dalam kegiatan yang dilakukan; 1) melafalkan huruf, 2) membedakan bunyi huruf yang memiliki simbol hampir serupa, 3) anak kesulitan dalam menyusun huruf menjadi sebuah kata, dan 4) anak kesulitan dalam menghubungkan gambar dengan simbol huruf. Oleh karenanya peneliti ingin mencoba memperbaiki kemampuan membaca permulaan tersebut dengan menggunakan media pembelajaran yang edukatif dan menarik untuk anak yang berupa "flannel pintar".

Flannel pintar ini semacam kartu bergambar tetapi lebih menarik bagi anak dalam memainkannya. Media ini diharapkan dapat menarik perhatian siswa 
karena disertai dengan gambar-gambar yang menarik. Media ini mudah dibuat, harganya murah, mudah didapat, dan huruf yang jelas dan tebal sehingga memudahkan anak untuk mempelajarinya. Selain itu, media ini juga dapat menunjukan pokok masalah karena gambar yang melambangkan benda-benda konkret yang ada di sekitar. Gambar memiliki kekuatan besar dalam merespon otak anak. Anak akan mudah memahami kata-kata yang dipelajarinya dengan melihat gambar. Dengan menggunakan media ini diharapkan anak kelompok A TK Negeri Pembina Bantul dapat belajar membaca dengan metode yang menyenangkan yaitu belajar sambil bermain dan kemampuan membaca mereka meningkat.

\section{Pengertian Kemampuan Membaca Permulaan}

Kemampuan merupakan proses pembelajaran yang mendukung perkembangan anak. Kemampuan merupakan kesanggupan, kecakapan, kekuatan untuk berusaha dengan diri sendiri (Mohammad Zain dalam Milman Yusdi, 2010: 10). kemampuan merupakan kecakapan individu dalam menguasai tugas yang diberikan. Kemampuan yang dimiliki setiap anak berbeda. Berbagai kemampuan yang dimiliki perlu dikembangkan agar kemampuan tersebut dapat optimal.

Membaca pada tingkat awal atau membaca permulaan dapat diberikan kepada anak di Taman Kanak-kanak. Hal ini tergantung pada kesiapan membaca anak. Tanda-tanda anak yang mempunyaikesiapan membaca menurut Nurbiana Dhieni (2005: 9.3) yaitu dapat memahami bahasa lisan, dapat mengucapkan kata dengan jelas, dapat mengingat kata-kata, dapat mengucapkan bunyi huruf, sudah menunjukan minat membaca, dan dapat membedakan suara atau bunyi dan objek dengan baik.Membaca permulaan merupakan proses mengenal bacaan yang dilakukan secara terprogram yang diperuntukkan untuk anak usia dini.

\section{Tahap Perkembangan Membaca Permulaan}

Anak usia TK memiliki perkembangan yang unik dalam membaca. Cochrane et.al dalam Nurbiana Dhieni (2005: 5.13), perkembangan dasar kemampuan membaca permulaan pada anak usia 4-6 tahun berlangsung dalam lima tahap yakni:

Tahap Fantasi (Magical Stage)

Pada tahap ini anak mulai belajar menggunakan buku, berpikir bahwa buku itu penting dengan cara membolak-balik buku berulang kali, dan suka membawa buku kesukaannya.

Tahap Pembentukan Konsep Diri (Self Concept Stage)

Anak memandang dirinya sebagai pembaca dan mulai melibatkan dirinya dalam kegiatan membaca, pura-pura membaca buku.

Tahap Membaca Gambar (Bridging Reading Stage)

Anak menyadari cetakan yang tampak, mulai dapat menemukan kata yang sudah dikenal, dapat mengulang kembali cerita yang tertulis, dan sudah mengenal abjad.

Tahap Pengenalan Bacaan (Take-off Reader Stage)

Anak mulai tertarik pada bacaan dan mulai membaca tanda-tanda yang ada di lingkungan seperti membaca kardus susu, bungkus makanan, pasta gigi, dan lainlain.

Tahap Membaca Lancar (Independent Reader Stage)

Anak dapat membaca berbagai jenis buku secara bebas. Orang tua dan guru masih harus tetap membacakan buku pada anak

Kegiatan membaca permulaan yang bermakna akan mempengaruhi kegiatan membaca pada tahap selanjutnya. Jeann Chall (dalam Aulia, 2011: 31-32) mengemukakan bahwa belajar membaca mencakup pemerolehan kecakapan yang dibangun pada keterampilan sebelumnya. 
Untuk mencapai hal ini, ada 5 tahapan perkembangan kemampuan membaca, yaitu:

Tahap Dasar (0)

Pada tahap ini ditandai ketika anak mulai menguasai prasyarat membaca dan membedakan huruf dalam alphabet. Kemudian anak dapat membaca beberapa kata yang sering ditemui seperti di televisi atau media lainnya. Hal ini dapat dikatakan bahwa anak sudah dapat membedakan antara pola huruf meskipun belum dapat mengerti kata itu sendiri.

Tahap 1

Tahap ini terjadi pada tahun pertama sekolah, anak belajar kecakapan merekam fonologi yang digunakan untuk menerjemahkan simbol-simbol ke dalam suara dan kata-kata.

Tahap 2

Anak sudah belajar membaca dengan fasih dan menguasai hubungan dari huruf ke suara serta dapat membaca sebagian besar kata dan kalimat sederhana

Tahap 3

Anak sudah bisa mendapatkan informasi dari materi yang tertulis. Anak akan belajar dari buku yang mereka baca.

Tahap 4

Pada tahap ini kemampuan membaca anak sudah sangat fasih. Anak menjadi semakin memahami beragam materi bacaan dan menarik kesimpulan dari apa yang ia baca.

\section{Pengertian Media}

Gagne (dalam Nurbiana Dhieni, 2008: 10.3) menyatakan bahwa media merupakan jenis komponen dalam lingkungan anak didik yang dapat memotivasi anak untuk belajar. Media untuk anak berbeda dengan media untuk orang dewasa. Media untuk anak akan bermakna jika media tersebut dapat disentuh dan digunakan langsung oleh anak. Anak berinteraksi dengan media yang digunakan agar media dapat bermakna dalam pembelajaran.

\section{Manfaat Media}

Media memiliki banyak manfaat. Nana Sudjana dan Ahmad Rivai (2002: 2) memaparkan bahwa banyak manfaat yang dapat diperoleh dengan memanfaatkan media dalam pembelajaran antara lain yaitu:

Pengajaran lebih menarik perhatian anak sehingga menumbuhkan motivasi belajar.

a. Bahan pengajaran lebih jelas maknanya sehingga dapat dipahami anak dan anak dapat menguasai tujuan pengajaran dengan lebih baik.

b. Metode mengajar dapat lebih bervariasi karena pengajaran tidak hanya dengan komunikasi secara verbal sehingga anak tidak cepat bosan.

c. Anak akan lebih banyak melakukan kegiatan belajar karena anak tidak hanya mendengarkan guru tetapi juga mengamati, melakukan, dan mendemonstrasikan.

\section{Pemilihan Media yang Tepat untuk AUD}

Kriteria pemilihan media menurut Nana Sudjana dan Ahmad Rivai (2005: 45) antara lain:

a. Ketepatan dengan tujuan pembelajaran. Hal ini dipilih atas dasar tujuan-tujuan instruksional yang ditetapkan. Tujuan tersebut berisikan unsur pemahaman, aplikasi, dan analisis yang memungkinkan digunakannya media tersebut.

b. Dukungan terhadap isi bahan pembelajaran.

Bahan pembelajaran yang sifatnya fakta, prinsip, konsep, dan generalisasi sangat memerluka bantuan media agar mudah dipahami.

c. Kemudahan dalam memperoleh media. Media sebaiknya mudah diperoleh, mudah dibuat oleh guru tanpa biaya mahal, sederhana, dan praktis penggunaannya.

d. Keterampilan guru dalam menggunakan media tersebut. 
e. Sesuai taraf berpikir siswa sehingga makna yang terkandung dapat dipahami anak dengan mudah.

\section{Pengertian Flannel Pintar}

Flannel Pintar adalah sejenis dengan kartu kata bergambar termasuk dalam jenis media visual, yaitu penerima pesan (anak) akan menerima informasi melalui indra penglihatannya karena pesan yang akan disampaikan dituangkan ke dalam simbolsimbol komunikasi visual (Nurbiana Dhieni, 2008: 11.13). Anak melihat gambar yang divisualkan dan huruf yang tertera dalam kartu.

Penggunaan media gambar dan kartu sangat cocok dengan karakteristik anak usia dini yang masih anak-anak. Aulia (2011: 84) mengatakan bahwa gambar memiliki kekuatan besar dalam merespon otak anak.

Pengertian di atas dapat disimpulkan bahwa flannel pintar sejenis kartu kata bergambar adalah media visual yang digunakan untuk pembelajaran membaca permulaan yang berupa kertas tebal yang berbentuk persegi panjang yang berisikan kata yang di dalamnya berisi gambar yang sesuai dan kata sesuai dengan gambar tersebut.

\section{Langkah-Langkah Pembelajaran Menggunakan Media Flannel Pintar}

a. Mempersiapkan media yang akan digunakan untuk pembelajaran.

b. Mengkondisikan anak sebelum pembelajaran dimulai dan membagi anak menjadi 4 kelompok.

c. Guru memberitahukan tema pembelajaran serta menjelaskan cara bermain dan memberi contoh.

d. Anak bergiliran untuk bermain.

e. Mengacak gambar dan satu per satu anak maju memilih 1 kartu dengan membaliknya.

f. Anak mengucapkan nama bendanya serta guru membimbing menyebutkan nama huruf awal dari nama benda tersebut. g. Anak menyebutkan nama-nama benda yang mempunyai suara huruf awal yang sama.

h. Anak belajar memahami hubungan bunyi dan huruf dengan menghubungkan tulisan dengan simbol yang melambangkannya dengan menempelkan kartu gambar dan kartu kata.

i. Anak menyebutkan kata yang mempunyai huruf awal yang sama dengan cara yang sama yaitu memilih 1 kartu dan membaliknya lalu anak menyebutkan kata yang mempunyai huruf awal yang sama.

j. Anak menyebutkan kata tersebut dengan jelas sehingga dapat dipahami oleh orang lain.

k. Guru selalu mendampingi dan memotivasi anak apabila ada yang mengalami kesulitan sehingga guru dapat membantunya.

\section{METODE PENELITIAN Jenis Penelitian}

Jenis Penelitian ini adalah Penelitian Tindakan Kelas (PTK).Subyek penelitian adalah anak kelompok A2 TK Negeri Pembina bantul yang berjumlah 22 anak. Sebagai kolaborator teman sejawat.

Penelitian ini menggunakan jenis Penelitian Tindakan Kelas (PTK) kolaboratif partisipatif. Suharsimi Arikunto (2010: 2) mengartikan Penelitian Tindakan Kelas secara partisipatif adalah kegiatan dengan adanya keterlibatan pihak lain di luar peneliti dalam melakukan penelitian. Penelitian tindakan kelas Menurut Hopkins (dalam Sarwiji Suwandi, 2009: 14) menyebutkan bahwa PTK memiliki karakteristik perbaikan proses pembelajaran dari dalam, usaha kolaboratif, dan bersifat fleksibel/disesuaikan dengan keadaan. Penelitian tindakan kelas merupakan bentuk penelitian yang dilaksanakan oleh seorang pendidik dalam kelas, materi disesuaikan dengan program pengajaran dan dilaksanakan bersamaan dengan proses belajar mengajar. Kegiatan 
penelitian tidak menganggu proses pembelejaran dan tidak dilaksanakan dalam waktu khusus.

\section{Waktu dan Tempat Penelitian}

Penelitian ini dilakukan di TK Negeri Pembina Bantul yang terletak di dusunTembiTimbulharjoSewonBantul,dala $m$ siklus yang tidakdapat ditentukan. Siklus dihentikan apabila penelitian ini mencapai kriteria keberhasilan.

\section{Target/Subjek Penelitian}

Subjek penelitian ini adalah anak kelompok A2 di TK Negeri Pembina Bantul yang berjumlah 22 anak yaitu 12 laki-laki dan 10 perempuan. Objek penelitian dalam tindakan ini adalah kemampuan membaca permulaan menggunakan media flannel pintar.

\section{Prosedur}

Peneliti ini menggunakan desain penelitian dari Kemmis dan Mc Taggart.. Model ini dikembangkan dari pemikiran Kurt Lewin (dalam Suharsimi Arikunto, 2010: 132) yang menggambarkan penelitian tindakan sebagai serangkaian langkah yang membentuk spiral. Model penelitian yang dipilih dalam penelitian ini adalah model siklus yang dilakukan secara berulang dan berkelanjutan. Proses pengulangan dilakukan untuk mendapatkan hasil yang optimal atau bisa dikatakan dapat meningkatkan proses dan hasil pembelajaran sesuai kriteria yang ditetapkan.

\section{Data, Intrumen, dan Teknik Pengumpulan Data}

Metode penelitian adalah cara yang digunakan oleh peneliti untuk memperoleh data yang dibutuhkan (Suharsimi Arikunto, 2010: 175). Pengumpulan data yang digunakan menggunakan metode observasi. Observasi dilakukan selama kegiatan pembelajaran menggunakan flanel pintar. Oservasi dilakukan untuk melihat kegiatan pembelajaran.
Observasi dilakukan dengan cara mengumpulkan data mengenai kemampuan anak dalam mengucapkan bunyi huruf, membedakan huruf, menyebutkan nama-nama benda yang mempunyai suara huruf awal sama, memahami hubungan bunyi dan huruf dengan menghubungkan tulisan dengan simbol yang melambangkannya, menyebutkan kata yang mempunyai huruf awal yang sama, dan melafalkan kata dengan jelas. Pengumpulan data dilakukandengan menggunakan lembar observasi yang didalamnya terdapat indikator-indikator yang harus diamati ketika anak melakukan kegiatan tersebut. Indikator digunakan untuk melihat peningkatan pada kegiatan penelitian yang dilakukan.

\section{Teknik Analisis Data}

Analisis data yang digunakan dalam penelitian ini adalah analisis data deskriptif kualitatif-kuantitatif. Menurut Wina Sanjaya (2009: 106), analisis data adalah proses mengolah dan mengintepretasikan data dengan tujuan mendudukan berbagai informasi sesuai dengan fungsinya sehingga memiliki makna dan arti yang jelas. Analisis data kualitatif digunakan untuk menentukan peningkatanproses yang dinyatakan dalam sebuah predikat, sedangkan analisis data kuantitatif digunakan untuk menentukan peningkatan hasil dengan menggunakan persentase. Analisis kualitatif dalam penelitian ini dinyatakan dalam sebuah predikat yang menunjuk pada pernyataan keadaan dan ukuran kualitas sehingga hasil penilaian berupa bilangan kemudian diubah menjadi sebuah predikat. Dalam penelitian ini, peneliti menggunakan predikat BB (Belum Berkembang), MB (Mulai Berkembang), BSH (Berkembang Sesuai Harapan), BSB (Berkembang Sangat Baik) yang kemudian didiskripsikan. 
HASIL

PENELITIAN

DAN

PEMBAHASAN

Hasil Penelitian

Tabel 1. Kemampuan Membaca Permulaan Anak Pra Tindakan

\begin{tabular}{|c|c|c|c|c|}
\hline No & $\begin{array}{l}\text { Pencapaian } \\
\text { Persentase } \\
\text { Kemampuan } \\
\text { Membaca Permulaan }\end{array}$ & $\begin{array}{l}\text { Jum } \\
\text { lah } \\
\text { Anak }\end{array}$ & $\begin{array}{l}\text { Per } \\
\text { sentase }\end{array}$ & $\begin{array}{l}\text { Kri } \\
\text { te } \\
\text { ria }\end{array}$ \\
\hline 1. & $\begin{array}{l}\text { Anak yang } \\
\text { memperoleh } \\
0 \%-50 \% \text { dalam } \\
\text { kemampuan membaca } \\
\text { permulaan }\end{array}$ & 4 & $25 \%$ & BB \\
\hline 2. & $\begin{array}{l}\text { Anak yang } \\
\text { memperoleh } \\
51 \%-66 \% \text { dalam } \\
\text { kemampuan membaca } \\
\text { permulaan }\end{array}$ & 10 & $\begin{array}{c}83,3 \\
\%\end{array}$ & MB \\
\hline 3. & $\begin{array}{l}\text { Anak yang } \\
\text { memperoleh } \\
67 \%-83 \% \text { dalam } \\
\text { kemampuan membaca } \\
\text { permulaan }\end{array}$ & 6 & $50 \%$ & BSH \\
\hline 4. & $\begin{array}{l}\text { Anak yang } \\
\text { memperoleh } \\
84 \%-100 \% \text { dalam } \\
\text { kemampuan membaca } \\
\text { permulaan }\end{array}$ & 2 & $\begin{array}{c}16,6 \\
\%\end{array}$ & BSB \\
\hline & Jumlah & 22 & & \\
\hline
\end{tabular}

Tabel 2. Data Kemampuan Membaca Permulaan Anak pada Siklus I

\begin{tabular}{|c|c|c|c|c|}
\hline No & $\begin{array}{l}\text { Pencapaian } \\
\text { Persentase } \\
\text { Kemampuan } \\
\text { Membaca Permulaan }\end{array}$ & $\begin{array}{l}\text { Jum } \\
\text { lah } \\
\text { Anak }\end{array}$ & $\begin{array}{l}\text { Per } \\
\text { sentase }\end{array}$ & $\begin{array}{l}\text { Kri } \\
\text { te } \\
\text { ria }\end{array}$ \\
\hline 1. & $\begin{array}{l}\text { Anak yang } \\
\text { memperoleh } \\
0 \%-50 \% \text { dalam } \\
\text { kemampuan membaca } \\
\text { permulaan }\end{array}$ & 2 & $\begin{array}{l}16,6 \\
\%\end{array}$ & BB \\
\hline 2. & $\begin{array}{l}\text { Anak yang } \\
\text { memperoleh } \\
51 \%-66 \% \text { dalam } \\
\text { kemampuan membaca } \\
\text { permulaan }\end{array}$ & 8 & $\begin{array}{l}66,6 \\
\%\end{array}$ & MB \\
\hline 3. & $\begin{array}{l}\text { Anak yang } \\
\text { memperoleh } \\
67 \%-83 \% \text { dalam } \\
\text { kemampuan membaca } \\
\text { permulaan }\end{array}$ & 6 & $\begin{array}{l}50 \\
\%\end{array}$ & BSH \\
\hline 4. & $\begin{array}{l}\text { Anak yang } \\
\text { memperoleh } \\
84 \%-100 \% \text { dalam } \\
\text { kemampuan membaca } \\
\text { permulaan } \\
\quad \text { Jumlah }\end{array}$ & 22 & $\begin{array}{l}66,6 \\
\%\end{array}$ & BSB \\
\hline
\end{tabular}

Tabel 2. Data Kemampuan Membaca Permulaan Anak pada Siklus II

\begin{tabular}{|c|c|c|c|c|}
\hline No & $\begin{array}{l}\text { Pencapaian } \\
\text { Persentase } \\
\text { Kemampuan } \\
\text { Membaca Permulaan }\end{array}$ & $\begin{array}{l}\text { Jum } \\
\text { lah } \\
\text { Anak }\end{array}$ & $\begin{array}{l}\text { Per } \\
\text { sentase }\end{array}$ & $\begin{array}{l}\text { Kri } \\
\text { te } \\
\text { ria }\end{array}$ \\
\hline 1. & $\begin{array}{l}\text { Anak yang } \\
\text { memperoleh } \\
0 \%-50 \% \text { dalam } \\
\text { kemampuan membaca } \\
\text { permulaan }\end{array}$ & 0 & $0 \%$ & BB \\
\hline 2. & $\begin{array}{l}\text { Anak yang } \\
\text { memperoleh } \\
51 \%-66 \% \text { dalam } \\
\text { kemampuan membaca } \\
\text { permulaan }\end{array}$ & 2 & $\begin{array}{c}16,6 \\
\%\end{array}$ & MB \\
\hline 3. & $\begin{array}{l}\text { Anak yang } \\
\text { memperoleh } \\
67 \%-83 \% \text { dalam } \\
\text { kemampuan membaca } \\
\text { permulaan }\end{array}$ & 9 & $\begin{array}{l}75 \\
\%\end{array}$ & $\mathrm{BSH}$ \\
\hline 4. & $\begin{array}{l}\text { Anak yang } \\
\text { memperoleh } \\
84 \% \text { - } 100 \% \text { dalam } \\
\text { kemampuan membaca } \\
\text { permulaan } \\
\quad \text { Jumlah }\end{array}$ & 11 & $\begin{array}{c}91,6 \\
\%\end{array}$ & BSB \\
\hline
\end{tabular}

Prosentase Kenaikan Membaca Permulaan

\begin{tabular}{|c|c|c|c|c|}
\hline $\begin{array}{c}\mathrm{N} \\
\mathrm{O}\end{array}$ & Tindakan & Jumlah & Prosentase & Kriteria \\
\hline \multirow[t]{4}{*}{1} & \multirow[t]{4}{*}{ Pra tindakan } & 4 & $25 \%$ & $\mathrm{BB}$ \\
\hline & & 10 & $83,3 \%$ & MB \\
\hline & & 6 & $50 \%$ & $\mathrm{BSH}$ \\
\hline & & 2 & $16,6 \%$ & BSB \\
\hline \multirow[t]{4}{*}{2} & \multirow{4}{*}{$\begin{array}{l}\text { Siklus I } \\
22 \text { anak }\end{array}$} & 2 & $16,6 \%$ & $\mathrm{BB}$ \\
\hline & & 8 & $66,6 \%$ & MB \\
\hline & & 6 & $50 \%$ & $\mathrm{BSH}$ \\
\hline & & 6 & $50 \%$ & BSB \\
\hline \multirow[t]{4}{*}{3} & \multirow{4}{*}{$\begin{array}{l}\text { Siklus II } \\
22 \text { anak }\end{array}$} & 0 & $0 \%$ & $\mathrm{BB}$ \\
\hline & & 2 & $16,6 \%$ & $\mathrm{MB}$ \\
\hline & & 9 & $75 \%$ & BSH \\
\hline & & 11 & $91,6 \%$ & BSB \\
\hline
\end{tabular}

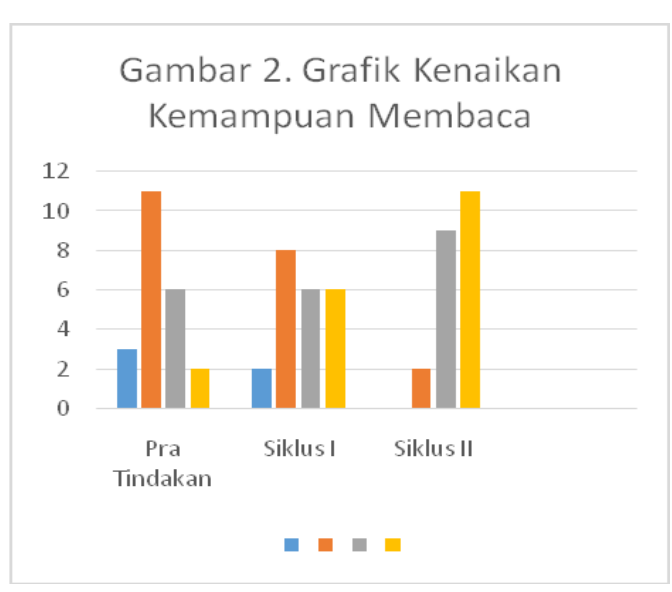

Gambar1. Grafik

kenaikankemampuanmembaca 


\section{PENUTUP}

Simpulan

Berdasarkan hasil penelitian dan pembahasan, maka peneliti menarik kesimpulan yaitu pembelajaran dengan menggunakan media flannel pintar mampu meningkatkan kemampuan membaca permulaan anak kelompok A2 di TK Negeri Pembina. Peningkatan tersebut dapat dilihat dan dibuktikan dari adanya peningkatan persentase dari sebelum tindakan, setelah dilakukan tindakan pada Siklus I dan setelah dilakukan tindakan pada Siklus II. Peningkatan dari pra tindakan ke Siklus I sebesar 50\% dan dari Siklus I ke Siklus II mengalami peningkatan sebesar 91,6\% ( BSB ).Adapun keberhasilan tersebut dilakukan dengan langkah-langkah sebagai berikut:

(1) mempersiapkan media dan mengkondisikan anak,

memberitahukan tema pembelajaran serta menjelaskan cara bermain dan memberi contoh serta membagi anak dalam 4 kelompok, (3) anak bergiliran untuk bermain dan mengacak kartu dengan posisi terbalik di kantung flannel dan satu per satu anak maju memilih 1 kartu dengan membaliknya, (4) anak bermain serta melakukan sesuai perintah dan contoh guru dalam pembelajaran kemampuan membaca pada indikator 1 sampai 6 sesuai yang direncanakan peneliti, dan (5) mendampingi dan memotivasi anak apabila ada yang mengalami kesulitansehingga guru dapat membantunya serta tidak memaksa anak untuk harus menjawab atau melakukan dengan benar.

Saran

Berdasarkan kesimpulan dari hasil penelitian di atas, peneliti memberikan saran sebagai berikut:

1. Bagi Guru

Dalam pembelajaran menggunakan media kartu kata bergambar ini, guru harus lebih mampu menguasai materi yang akan diajarkan dan mampu menggunakan dengan baik media yang digunakan. Dalam pembelajaran, guru harus mampu menciptakan suasana yang riang dan nyaman bagi anak serta selalu memberikan perhatian dan motivasi baik itu verbal, fisik, ataupun dengan hadiah/ reward. Guru juga bisa lebih memodifikasi kegiatan dengan kartu kata bergambar sehingga anak lebih aktif, antusias, dan cepat menangkap apa yang diajarkan.

2. Bagi Peneliti Selanjutnya

Peneliti selanjutnya harus lebih mampu untuk mengkreasikan media ini sehingga anak lebih tertarik. Pelaksanaan lebih dibuat bervariasi lagi melalui kartu kata bergambar ini sehingga anak menjadi aktif dan merasa mereka tidak seperti sedang belajar.

\section{DAFTAR PUSTAKA}

Arikunto, S. (2005). Manajemen Penelitian. Jakarta: PT Rineka Cipta.

Aulia. (2011). Mengajarkan Balita Anda Membaca. Yogyakarta: Intan Media.

Dhieni, N. (2005). Metode Pengembangan Bahasa. Jakarta: Universitas Terbuka

Yusdi, M. (2011). Pengertian Kemampuan. Diakses dari http://milmanyusdi.blogspot.com/ pada tanggal 23 Desember 2013, jam 13.45 WIB.

Permendikbud No. 137 Tahun 2014 tentang Standar Tingkat Pencapaian Perkembangan Anak. Jakarta: Depdikbud.

Permendikbud No. 146 Tahun 2014 tentang Standar Tingkat Pencapaian Perkembangan Anak. Jakarta: Depdikbud. 
Sanjaya, W. (2009). Penelitian Tindakan

Kelas. Jakarta: Kencana Prenada Media Group.

Sudjana, N., Rivai A., Rivai, A. (2002). Media Pengajaran. Bandung: Sinar Baru Algensindo Offset. 